Игор Д. ПЕРИШИЋ

Институт за књижевност и уметност

Београд
Оригинални научни рад

Примљен: 05. 11. 2019.

Прихваћен: 12. 02. 2020.

\title{
ГРОБНИЦА ЗА БОРИСА ДАВИДОВИЧА ДАНИЛА КИША КАО ЕНЦИКЛОПЕДИЈА ИДЕОЛОГИЈА СМРТИ ${ }^{* *}$
}

\begin{abstract}
У време када је објављена, Гробница за Бориса Давидовича била је веома храбра, чак брутална критика тоталитарних идеологија, како оних друштвено-политичких тако и поетичких. После разматрања левог и десног тоталитаризма у Кишовој књизи (пре свега у причама „Ножа са дршком од ружиног дрвета” и „Пси и књиге”), поставља се питање какав је био пишчев став према још једној - овога пута поетичкој - идеологији смрти: теорији о смрти аутора (у причи „Кратка биографија А. А. Дармолатова (1892-1968)”). На основу тога, износе се хипотезе зашто је Данило Киш у својим енциклопедијама идеологија смрти на неки начин ипак „поштедео” идеологију југословенског социјализма (титоизма).

Кључне речи: енциклопедијска парадигма, идеологија, бољшевизам, стаљинизам, фашизам, југословенски социјализам, смрт аутора, Данило Киш, Гробница за Бориса Давидовича.
\end{abstract}

У време када се појавила, 1976. године, чврсто увезана збирка прича ${ }^{1}$ Данила Киша Гробница за Бориса Давидовича изазвала је „мали рат” у српској књижевности, који се водио како на страницама књижевних часописа, тако и у широј јавности, а резултирао је значајним полемичким студијама Час анатомије (1978) самог Киша и Нариис без лица (1981) Драгана Јеремића. ${ }^{2}$ У протопостмодернистичкој енциклопедијској парадигми, Данило Киш је у Гробници створио за то време невиђено бруталан каталог злочина̂ тотали-

"perisigor@gmail.com

** Текст је резултат рада на научноистраживачком пројекту „Културолошке књижевне теорије и српска књижевна критика” (178013), који финансира Министарство просвете, науке и технолошког развоја Републике Србије.

${ }^{1}$ Уз још неке претходне тумаче, Драган Бошковић у књизи Иследник, сведок, прича са добрим разлозима доказује да је реч о роману (Бошковић 2004).

${ }^{2}$ Приликом данашњег читања књиге Нариис без лица Драгана Јеремића, предводника табора супротстављеног Данилу Кишу и поетици Гробнице за Бориса Давидовича, које би апстраховало полемички контекст и заблуде непризнавања нове поетике, пронашао би се низ луцидних и тачних запажања само ако би им се уклонио негативни вредносни предзнак. Више о полемици Киш-Јеремић у: Перишић 2007: 67-69. 
тарних идеологија у распону од шест векова историје, како оних друштвенополитичких тако и поетичких. За тако циничан, а поетички скоро савршено изведен обрачун пре свега са бољшевизмом и стаљинизмом, било је у то доба потребно много храбрости у домаћем контексту, оптерећеном нелагодом због импликација које су могле бити успостављене у односу на југословенски социјализам (Киш га ипак директно не „прозива”), али још и више у контексту западних интелектуалних кругова којима је и сам Киш припадао, у време док су неки леви интелектуалци негирали стаљинистичке злочине. ${ }^{3}$

У књизи о Кишу, Владимир Зорић добро описује западни интелектуални контекст у који је ступила Гробница за Бориса Давидовича. Крајем 1973. године у Паризу објављен је први том мемоарске прозе Александра Солжењицина, Архипелаг Гулаг, а француска Комунистичка партија започиње кампању против књиге у знак подршке совјетској влади. У француским левичарским круговима, Солжењицинова књига доживљена је као акт десничарске завере (Зорић 2005: 53). Нешто касније у својој студији, Зорић долази до занимљиве претпоставке:

[...] чини се, наиме, да средишња тема Кишове књиге и није тоталитарни поредак per se, него доживљај таквог поретка из перспективе западних интелектуалаца (Зорић 2005: 60).

Усвајајући западноевропску антитоталитарну перспективу (најпре ону Хане Арент о изворима тоталитаризма), ${ }^{4}$ у својој аксиоматској и холистичкој концепцији односа идеологије и историје, Киш је сматрао да „Холокауст и совјетски гулази по својој нечовечној суштини представљају аналогне појаве" (Зорић 2005: 50). На основу тога, он је изједначавао све тоталитарне режиме, пре свега совјетски бољшевичко-стаљинистички и немачки национал-социјалистички. О овом другом је довољно говорио у књигама које су претходиле Гробници, понајвише у Пешчанику. Сама Гробница за Бориса Давидовича, иако јесте повест о разним тоталитаризмима током историје, на првом месту ипак је хроника једног ужег временског периода.

У Гробници за Бориса Давидовича доминантна критика левих тоталитарних идеологија, пре свега бољшевизма и стаљинизма, на најбруталнији начин избија у уводној причи „Нож са дршком од ружиног дрвета”, која in nuсе представља и поетички и идеолошки постамент целе књиге. ${ }^{5}$ У поднаслову

\footnotetext{
${ }^{3}$ Владимир Гвозден примећује да је Гробницом Данило Киш на идеолошком плану хтео да иступи против западног (француског) левичарског догматизма: „Кишова интервенција је највише усмерена на откривалачко приповедање, односно на комеморацију онога што је званична истина заобилазила, са амбициозним циљем да се промени сам образац културног памћења. Киш је упозоравао да је стварност совјетских логора нешто што се не признаје, код француских интелектуалаца, на пример, јер би то признање подразумевало несагледиву интервенцију у свету утврђених представа" (Гвозден 2006: 435).

4 „У том смислу је Кишов приступ веома сличан синтетичком облику разматрања теоретичара попут Хане Арент, који тврде да није толико битно да ли тоталитарни покрети попримају нацистички или бољшевички облик, да ли грађане окупљају у име расе или у име класе, нити да ли се позивају на природно право или дијалектику историје” (Зорић 2005: 55).

${ }^{5}$ Насловни нож се појављује и у роману Башта, пепео (који се пре свега бави десним тоталитаризмом), чиме Киш, сматра Божо Копривица, потцртава своју опсесивну тему - успостављање аналогија између стаљинизма и фашизма (Копривица 1990).
} 
иронијски назван позитивним јунаком приче, Микша (Михаил Хантеску) већ на почетку „гледа у далеку будућност осветљену огромним пламеном” (Киш 1998: 22), чиме добијамо фигуру антиципације резултата револуционарних идеологија. Јунак несигурног порекла, заправо карактеристични кишовски амалгам човека средњоевропског културног простора, кроз целу причу представљаће иронијску персонификацију наводно усрећитељске, на антрополошком оптимизму засноване, идеологије комунизма. Иронија је у томе што би се антрополошки оптимизам, барем у начелу, имао оваплотити и у јунаку који је традиционално речено „позитиван”, а Микша је све само то не. Наивна хегеловска вера у сврховитост историје, вера да се правда може остварити на земљи „средствима земаљским” (Киш 1998: 23), биће отпрве саркастично поништена тиме што ће се овај носилац апсолутног духа малопомало представљати као бесловесни поборник насиља, а потом и убица. ${ }^{6}$ Њега покреће искључиво мржња, и то вишеструко наглашена. Мржња потиче из обећања да ће се осветити онима који су му нанели увреде. Али увреде нису биле последица његовог класног порекла и багажа који уз то следује, како би то требало да буде у једној правоверној марксистичкој биографији. Неправде њему нанесене биле су исте као „неправде” према осталим разбојницима с којима је био у блиском контакту и с којима се удружује у истој мржњи. Мржња као покретач освете ,лумпенпролетаријата” резултираће активистичком пројекцијом тоталитарне утопије која врхуни у деструкцији постојећег света, без примисли о антитоталитарном реформском духу. На делу је само револуционарни порив за чишћењем света од „керова, господе и ловачких рогова" (Киш 1998: 25).

Иронија спрам налога за револуцијом која мора стално да тече транспонована је кроз Микшину бригу да случајно „не би у њему отупела револуционарна оштрица” (Киш 1998: 25). Тако се и његова вера у могућност револуционарне промене света, удружена са истом менталном мапом другог разбојника, претвара у веру у мржюу. Како би таква мржња била цинички апсурдна, потребно је било да Микшина жртва буде од људи истог кова. Да би она постала још суровија, на месту човека истог кова нашла се - жена. У „обданишту” револуције у којем треба да се докаже за будућа већа дела, Микша добија задатак да убије Хану Кжижевску, која је „била беспрекорна у својој схематичности" (Киш 1998: 27). Осим мале мрље у виду грађанског порекла, она је такође била све-по-пропису револуционарка. Овом, како сам Киш истиче, схематизацијом ликова у причи, огољеним паралелизмом биографијаิ, подвлачи се и догматичност комунизма. Када би жртва била од различитог соја, или освета усмерена на неког из буржоаског света, онда мржња не би могла да покаже своју бесмислену конструисаност. Овако ће се цинично испоставити да ће Микша симболички убити заправо себе, само - игром приповедачке ироније - у обличју Другог тела.

6 За разлику од неких других ликова из Гробнице, како примећује Ала Татаренко, Микша уопште не размишља, њега не муче никакве сумње: „Микша не сумња кад извршава злочин, нити кад пише признање које ће одвести у смрт двадесетак недужних људи (не заборавивши да помене оне који су му се некада замерили)" (Татаренко 2013: 66). 
Речи које следе након неуспешне полицијске истраге убиства активираће још једном, као завршни заобилазни ауторски коментар, семантички потенцијал речи „мржња” у новом светлу: „Случај је, упркос извесним сумњама, наводио на помисао о злочину из страсти и као такав, после шестомесечне узалудне истраге, стављен ad acta" (Киш 1998: 29). Неспособност истражних органа да реше случај исказана је тиме што се рутински, када нема других доказа, убиство жене од стране мушкарца карактерише као злочин из страсти. Међутим, Кишово приповедачко мајсторство је у обрту трагичке ироније. Наиме, реч је била о злочину из страсти (мржње), јер се убиство, како је нетом пре тога описано, десило са „праведном мржњом која даје замах његовој руци" (Киш 1998: 28). Злочин се, дакле, заиста десио из (револуционарне) страсти. Као контраст таквој страсти, на крају приче појавиће се наоко од било какве емоције очишћен факат: „Михаил Хантеску умро је од пелагре у логору Известково, уочи нове године 1941" (Киш 1998: 32). ${ }^{7}$ Безличност фактографије требало би да послужи емотивној редукцији, али механизмом трагичкоиронијског обрта последња реченица постаје емотивно „набијен” завршетак у којем се још једном подвлачи да је Микша страдао од онога што је и сам делимично створио кроз свој револуционарни „рад”.

Киш је одиста, кроз целу Гробнииу за Бориса Давидовича, бруталан према фанатизму револуционара, са своје стране их и приповедачки цинично кажњавајући хладним, фактографским наративом којим се углавном сугерише само један могући излаз: онај иронијски по којем револуција једе своју децу. Једна прича, цитирајући Џејмса Џојса, у наслову експлицитно даје ту метафору: „Крмача која прождире свој окот”, док прича „Магијско кружење карата" прави уверљиве паралеле између структура̂ стаљинистичког система и криминалних организација, где глава увек виси у торби, тј. зависи од воље случаја. У причи „Гробница за Бориса Давидовича” чак се нуди и физиолошко објашњење како револуционарна страст изнутра изједа оне који јој подлегну: Борису Давидовичу су ослабљена плућа, бубрези и зглобови, а узроци су дуге године робовања и ,револуционарни занос који се храни крвљу и жлездама" (Киш 1998: 100).

Тоталитарно насиље, које се структурално интериоризовано окреће против својих заступника, није карактеристично само за тзв. леве идеологије. У целину Гробнице за Бориса Давидовича Киш уноси и причу „Пси и књиге” (она се мора читати у контексту насловне приче „Гробница за Бориса Давидовича"), ${ }^{8}$ у којој се као контраст левом тоталитаризму појављује једнако

\footnotetext{
${ }^{7}$ Божо Копривица примећује да су у причама Гробнице последњи пасуси, епилози или постскриптуми, обележени хумором у сенци смрти: читалац се као у некој иронизованој бајци обавештава како су даље живели главни јунаци (Копривица 1990: 357). А живели су углавном тако што су убијени или умрли у логорима.

8 Драган Бошковић налази дванаест момената у којима се „пресликавају” биографије Бориса Давидовича Новског и Баруха Давида Нојмана: 1) иницијали њихових имена; 2) средње име; 3) подударност у датумима и годинама хапшења; 4) датум и године смрти; 5) „васкрсавање” двадесет година након смрти; 6) технике иследничког суочења; 7) идеје и дилеме; 8) одузимање (уништавање) књига; 9) профил интелектуалца; 10) једноумни, гномички став на основу којег су оптужени; 11) боравак у подрумским просторијама у истом ,друштву; 12) тоталитарни контекст (Бошковић 2004: 201-204).
} 
суров клерикални протофашизам средњевековне инквизиције. Да би се десни тоталитаризам увео на велику сцену било је потребно направити мали „увод” у којем се, у причи „Гробница за Бориса Давидовича”, антиципира потоња судбина Баруха Давида Нојмана, главног јунака приче „Пси и књиге”. Наиме, отац Бориса Давидовича, Давид Абрамович, као Јеврејин присилно учествује у једном хришћанском обреду. Руска царска коњичка регимента 1885. године слави Богојављење тако што ископа рупу у залеђеном Дњепру и ту обавља обредно пливање за крстом, при чему се успостављају нелагодне интеристоријске везе са „сличним” ритуалним фашистичким злочином из јануара 1942. године на новосадском дунавском леду над Србима, Јеврејима и Ромима, који је обрађен понајвише у роману Пешчаник. Киш је као седмогодишње дете за длаку избегао судбину дављења у залеђеном Дунаву, а јунак приче „Гробница за Бориса Давидовича” бива кажњен принудним пливањем за „часним” крстом и наливањем алкохолом, пошто је претходно бичеван и онесвешћен.

Религиозни тоталитаризам и фашизам поновиће се и у случају Баруха Давида Нојмана, јунака приче „Пси и књиге”. Иако се овај Јеврејин био силом покрстио, од њега се захтевало да буде још правовернији у изнуђеном конвертитству. Не успевши да издржи насиље клерототалитаризма инквизиције, Нојман ће по свој прилици издахнути на мукама. У овој причи, чија се радња одвија шест стотина година пре оне о Борису Давидовичу, исти су механизми доушништва који доводе до покоља у име вере. Пародијом библијског говора дочарава се како су Христови „војници”, верујући у једну истину, долазили до просте дијалектике по којој је било оправдано физички одстрањивати здраве од нездравих, тј. оне који верују у „праву” истину од оних иноверних. Хладна концептуализација оваквих идеја проузроковаће једну од првих некрополитика познатих у историји: интелектуалну припрему физичке елиминације непоћудних тела изводиће инквизиција, док се за конкретну изведбу увек може наћи довољно индоктриниране светине.

Идеолошки постамент хришћанске некрополитике налази се у следећим, често цитираним речима из приче „Пси и књиге”, које се могу узети као манифест против једноумља или једнокњижја. Изговара их Барух Давид Нојман:

И рекох им да их не цепају, јер многе књиге нису опасне, опасна је само једна; и рекох им да не цепају, јер читање многих књига доводи до мудрости, а читање једне једине до незнања наоружаног махнитошћу и мржњом (Киш 1998: 123).

У овом случају та опасна једна књига која производи злочине јесте Нови завет. Верници једне истине сматрају да друге књиге које говоре о нечему чега нема у овој књизи треба спалити јер су јеретичке, а сходно томе и некад симболички а понекад и физички жртвовати људе који своје истине траже у другим књигама. Лек против оваквог верског фанатизма, који често прелази у протофашизам, помиње се у једној фусноти приче, а то се има сматрати и Кишовим етичким ставом, јер га је често варирао и у нефикционалним текстовима. Наводећи да су у једној области Јевреји имали право да живе сло- 
бодно, захваљујући одлуци (либералног) инквизитора Арноа Дежана, транслатор ове приче, заправо њен имплицитни аутор који преноси глас фигуре аутора, закључује да:

[...] лични став и грађанска храброст у тешким временима могу да измене судбину коју кукавице сматрају неминовном и проглашавају је фатумом и историјском нужношћу (Киш 1998: 130).

Као што је понекад било грађански храбрих комуниста који су се супротстављали наративима формираним на марксистичкој догми о епистемолошки прозирној сврховитости историје, тако је аутор Гробнище пронашао и пример „доброг инквизитора” како би указао на значај либералног индивидуализма у опреци са тоталитаризмима заснованим на присилној „колективизацији духа".

Причом „Кратка биографија А. А. Дармолатова (1892-1968)” Киш критику левих и десних политичких идеологија смрти пребацује на поетички план, при чему се на један посредан начин обрачунава са амбивалентном идејом смрти аутора. ${ }^{9}$ Заслужни уметник и дворски песник Дармолатов на поетичком плану је заступник вулгарног материјализма, чиме ће се под иронијску суспензију довести поетичка идеологија соц-реализма, која би због свог и формалног и садржинског редукционизма, да није на концу ипак одбачена, значила и смрт књижевности као слободне духовне креације. Попут злочинца Микше, кога смо у причи „Нож са дршком од ружиног дрвета” упознали како дере живог твора, и Дармолатов своју едукацију започиње асистирајући оцу при вивисецирању глодара, да би касније постао песнички медиокритет, који ће метафикционално означити смрт антиматеријалистичког аутора: његова поезија врви од емпиријских чињеница и правоверних соц-реалистичких тема. Након каталога тих тема и максимално сажете и иронизоване биографије, следи постскриптум у којем се симболички сажима читав његов поетски безвредан живот:

Остаје у руској литератури као медицински феномен: случај Дармолатова ушао је у све новије уџбенике патологије. Снимак његових мошњи, величине највеће колхозне тикве, прештампава се и у страним стручним књигама где год је реч о елефантијазису (elephantiasis nostras) и као наравоученије писцима да за писање нису довољна само муда (Киш 1998: 142).

\footnotetext{
${ }^{9}$ И код Ролана Барта, који је лансирао идеју о смрти аутора, увек остаје довољно простора за иронијски одмак од сопствених ставова, које он понекад и интенционално побија или подвргава аутополемици. Проучавајући функције ауторских коментара у Кишовој прози, Ивана Миливојевић примећује да је Бартова теорија о смрти аутора с једне стране представљала радикални раскид са класичним схватањем ауторског ауторитета, док је, с друге, била полемичка иницијација за преиспитивање нових облика појављивања ауторске фигуре (Миливојевић 2001: 221-222). Теорија о смрти аутора је, тако, послужила као алтернативно име за поступак цитатности, интертекстуалности и детронизације свезнајућег приповедног Ја, али ова идеја код Киша, сматра Данило Коцески, „не значи једноставно поништење индивидуалности, већ проширење стандардних приповедачких видокруга" (Коцевски 1990: 391-392).
} 
Наводећи да је Киш називао ову причу - нарочито због унеколико загонетног, курзивом истакнутог постскриптума - басном или алегоријом са наравоученијем, Јован Делић тумачи да је новела:

[...] полемички усмјерена на она схватања књижевности која вриједност књижевног дјела мјере мошњама: на примитивно-мужјачке, али и психоналитичке погледе на књижевност кроз (хипер) сексуалност (Делић 1997: 374).

Делић је у праву што се тиче једног од могућих тумачења овог вишезначно иронијског места из Кишове приче, али пропушта да симболику „муда” разграна бар у још једном могућем правцу. То би била иронија спрам громопуцателне соц-реалистичке поетике у којој би се „муда” имала читати као метафорички налог за приказивањем стварности уз „храбро” суочавање с проблемима новог, социјалистичког човека у изградњи бескласног друштва, а без било какве сумње или ироније. Ако се пише „из муда” онда нема места поетички либералном духу финесе, већ само за неспорне закључке који су и непесничке револуционаре водили директно у смрт. Соц-реализам би тако, неиронијски казано, представљао смрт аутора у име безличне Револуције која мора да тече не обазирући се на случајне ауторске жртве.

У овој причи занимљиво је још једно поетичко-идеолошки сигнификантно место: Кишово директно ауторско појављивање. Наиме, 1947. године Дармолатов долази на Цетиње, на прославу јубилеја Горског вијенц̧а:

Иако већ у годинама, незграпан и тром, младићки је прекорачио преко црвене свилене врпце која је Његошеву голему столицу, налик на престо каквог бога, одвајала од песника̂ и од смртника. Ја (ја који причам ову причу) стајао сам са стране и посматрао како се копрца песник-самозванац у високој, аскетској столици Његошевој [...] (Киш 1998: 142, подвукао И. П.).

Директним појављивањем у овој причи, Данило Киш (заиста је живео на Цетињу у периоду 1944-1954, када се одиграла и фиктивна посета Дармолатова) још једном доводи у питање поетичку идеологију смрти аутора, инсистирајући на конкретној биографској паралели са самим собом као аутором, који колико је то могуће у оквиру фикционалног текста изражава лични поетички и идеолошки став. Међутим, с друге стране, метафикционално прочитано (да ли ипак довољно јасно, с обзиром на строге етичке налоге његове прозе?) ово би требало да укаже и на стаљинистичке поступке у социјалистичкој Југославији - о којима није директно писао у Гробници - јер се до ужасне гротеске доводе културно-пропагандне манифестације тадашње државе. При томе, и фигура Његоша има метафикционално значење, као фигура ,јогија”, из чувене Кишове дихотомије јоги/комесар (преузете од Артура Кестлера), овде у опозиту са вулгарном соц-реалистичком или комесарском поетиком Дармолатова, који своје коначно гротескно обличје добија када седне у ,аскетску” Његошеву столицу.

Осим у документарном ТВ серијалу о Голом отоку под називом Голи живот, који је урадио са режисером Александром Мандићем (снимање се одвијало 1989. године, а четвороделна серија први пут је приказана после пишчеве смрти, 1990. године), Данило Киш ће тему југословенског тотали- 
таризма (титоизма) обрадити у књижевности узгред, ван магистралног тока свог опуса. Причу „Песник” о пензионисаном чиновнику који крајем 1945. године пише сонет против Тита и партије - да ли због „комедијанта смрти” или из других разлога - неће објавити за живота. ${ }^{10}$ Учиниће то, постхумно, његова прва супруга Мирјана Миочиновић, приређујући збирку прича Лаута и ожиљии (1994). Будући да прича нема довољан уметнички капацитет, оправдано је претпоставити да је Киш и из тих разлога није унео у целину Енциклопедије мртвих, мада је вероватно настала у том периоду, а њени корени, према Миочиновићевој, налазе се још у „крхотинама прибележених сећања везаних за цетињско раздобље пишчевог живота" (Киш 1994: 106). Наиме, реч је о, за писца „великих тема”, некарактеристично сатирично, помало и комичко приказаној биографији једног случајног дисидента, гогољевског лика без биографије. Господина Личину, писца инкриминисаног сонета, хапсе донекле монтањарски живописни али ипак карактерно недовољно разрађени службеници државне безбедности. У борби са иследницима, који су тек далеки одјек демонске интелигенције Федјукина из Гробнице, несуђени песник успева да преправи сонет тако да буде на партијској линији. То јест, у увелико анегдотском сижеу, службе приморавају Личину да значење песме потпуно измени, понекад се и завитлавајући с њим, а без физичке тортуре. Трагично бива то што се аутор сонета, после двогодишње робије, када изађе на слободу - обеси. Међутим, тај чин нема ону привидну фактографску неутралност из које еманира историјски трагизам, како је то био случај код јунака Гробнице за Бориса Давидовича.

Комички и иронијски тон у „Песнику” постоји и у вези са соц-реализмом, и то у односу према једном од његових званичких идеолога. Наиме, иследник у једном тренутку наређује Личини да ради још три месеца на преправљању песме: „Да буде ко да ју је саставља Зоговић! Јеси ли ме разумио. Ко Зоговић” (Киш 1994: 75). Будући да је Радован Зоговић, после периода када је био у милости новог режима, касније као русофил и догматски комуниста пао у немилост, с добрим разлозима се може претпоставити да његово помињање није могло бити опасно у време Кишове највеће књижевне славе. Зашто ова директна жаока у односу на културну идеологију југословенског социјализма није могла бити уклопљена у енциклопедију идеологија смрти, као домаћи прилог свеопштој историји бешчашћа? Подједнако би биле ваљане две хипотезе. Прва је већ поменута. Као писац који је врло пажљиво бирао шта ће објавити и који није имао значајних квалитативних падова у свом опусу, причом „Песник” заиста би донекле унизио сопствену поетичку савест. Али, да ли ју је вредело ипак објавити из етичких разлога? Друга хипотеза води ка томе да је Киш ипак, као интелектуалац лево-либералног

\footnotetext{
${ }^{10}$ Исто ће се десити са сатиричном поемом „Песник револуције на председничком броду”, која улази у поетички круг тема око „Кратке биографије А. А. Дармолатова”. Ова винаверовска пародија усмерена је, по свему судећи, на лик и дело Добрице Ћосића. У њој се иронијски преиспитује идеологија југословенског социјализма, као и њене пропратне полтронске манифестације. Поема је настала 1986. године, а објављена је у Кьижевним новинама 1989. године, у броју од 1. новембра, две недеље после пишчеве смрти.
} 
профила, ${ }^{11}$ сматрао југословенски социјализам (титоизам) идеологијом која не може бити сврстана у исту раван са стаљинизмом и национал-социјализмом, већ тек фуснотом на главном току идеологија смрти. То не значи да у контексту тоталитаризама нижег интензитета не би било места и за наратив југословенске варијанте пута ка светлој будућности. Међутим, у списатељском замаху обраде великих историјских катастрофа, Киш као да је наслутио да неће стићи да се позабави „ситнијим” темама. Ауторска појава на крају Гробнице за Бориса Давидовича, борхесовски чудесно, указује на будућа празна места његове (био)библиографије, која тиме бивају делимично антиципативно попуњена.

\section{ИЗВОРИ}

Киш 1994: Д. Киш, Лаута и ожиљи̧и, прир. Мирјана Миочиновић, Београд: БИГЗ.

Киш 1998: Д. Киш, Гробница за Бориса Давидовича, Београд: Књига-комерц.

\section{ЛИТЕРАТУРА}

Бошковић 2004: Д. Бошковић, Иследник, сведок, прича: Истражни поступци y Пешчанику $и$ Гробници за Бориса Давидовича Данила Киша, Београд: Плато.

Вељковић 2016: Д. Вељковић, Идеолошка позиција приповедача у Гробници за Бориса Давидовича Данила Киша, Годишњак за српски језик, бр. 14, $85-94$.

Гвозден 2006: В. Гвозден, Чињеница, траума и фикција: Ars memorativa у Гробници за Бориса Давидовича Данила Киша, у: 3. Карановић, С. Радуловић (ур.), Жанрови српске књижевности, Нови Сад: Филозофски факултет - Orpheus, 425-441.

Делић 1997: Ј. Делић, Кроз прозу Данила Киша: Ка поетиичи Кишове прозе 2, Београд: БИГЗ.

Копривица 1990: Б. Копривица, Тајни кључеви и страшна симетрија или нож са дршком од ружиног дрвета, Кюижевност, бр. 2-3, 346-362.

Коцевски 1990: Д. Коцевски, Смрт аутора у прози Данила Киша, Књижевност, бр. 2-3, 386-392.

Миливојевић 2001: И. Миливојевић, Фигуре аутора: Функције ауторског коментара у прози Данила Киша, Београд: Чигоја штампа.

\footnotetext{
11 Драгана Вељковић прецизније дефинише Кишову идеолошку позицију као грађански хуманизам, уз залагање за етику индивидуалне одговорности и подршку грађанском и литерарном ангажману (Вељковић 2016). Додајмо да Киш показује јасну дистанцираност од свих некрополитика (идеологија смрти), чувајући се било какве примисли о оправданости жртвовања људског живота зарад „виших” принципа.
} 
Перишић 2007: И. Перишић, Гола прича: Аутопоетика и историја у Гробници за Бориса Давидовича Данила Киша, Новом Јерусалиму Борислава Пекића и Фами о бициклистима Светислава Басаре, Београд: Плато - Институт за књижевност и уметност.

Татаренко 2013: А. Татаренко, Поетика форме у прози српског постмодернизма, Београд: Службени гласник.

Igor D. Perišić

\section{A TOMB FOR BORIS DAVIDOVICH AS AN ENCYCLOPAEDIA OF IDEOLOGIES OF DEATH}

(Summary)

In the proto-postmodernist encyclopedic paradigm, Danilo Kiš created at $A$ Tomb for Boris Davidovich an unprecedentedly brave, even brutal, catalogue of atrocities of totalitarian ideologies, spanning six centuries of history, both socio-political and poetic. In $A T o m b$, however, the dominant critique of "leftist" totalitarian ideologies, above all Bolshevism / Stalinism, was observed on the example of the introductory story "The Knife with the Rosewood Handle", which has so far not received much attention in literature, but story in nuce represents both poetic and the ideological basis of the whole book. An example of criticism of "right" ideologies of death was the story "Dogs and Books" (which must be read in the context of the cover story "A Tomb for Boris Davidovich"), in which the equally cruel clerical proto-fascism of medieval inquisition appears as a contrast to leftist totalitarianism. Finally, the story "A Short Biography of A. A. Darmolatov (1892-1968)", critique of left and right political ideologies of death switches into a poetic plane, in which Kiš indirectly deals with the posthumanist idea of the Death of the author, but also with the poetics of social realism as one that certainly led to death of literature. 